\title{
并合双星系统的引力波理论模型
}

\author{
蔡荣根 ${ }^{(1)}$, 曹周键 ${ }^{2 *}$, 韩文标 ${ }^{(3)}$ \\ (1) 中国科学院理论物理研究所, 北京 100190 ; \\ (2) 中国科学院数学与系统科学研究院, 北京 100190; \\ (3) 中国科学院上海天文台, 上海 200030 \\ *联系人, E-mail: zjcao@amt.ac.cn
}

2016-03-04 收稿, 2016-03-10 修回, 2016-03-11 接受, 2016-04-06 网络版发表

国家自然科学基金(11375260, U1431120)资助

\begin{abstract}
摘要引力波直接探测已经被LIGO成功实现. 在GW150914的数据处理中引力波理论模型起到了关键作用. 理 论模型不仅从原始数据的噪声中挖掘出引力波信号, 使得探测结果的置信度达到 $5.1 \sigma$, 而且还证认出其波源是并 合的双黑洞. 除了LIGO这样的地面引力波探测器, 还有脉冲星计时计划和空间引力波探测计划等. 在所用的这些 引力波探测计划中，理论模型都扮演着信号提取和波源反演的重要角色. 随着引力波天文学的逐渐开展，理论模 型研究的重要性和紧迫性将变得越来越明显. 双星系统是上述所有引力波探测计划最为重要和最为现实的波源. 本文对双星系统的引力波理论模型研究现状作一个概括性介绍, 并指出存在的问题和以后可能的研究方向.
\end{abstract}

关键词引力波, 双星系统, 数值相对论, 后牛顿近似, 黑洞微扰理论, 爱因斯坦方程

引力波是广义相对论最重要的理论预言之一, 最早由爱因斯坦在1916年提出. 但由于爱因斯坦广 义相对论满足微分同胚不变性, 人们对引力波的物 理真实性有过长时间的讨论 ${ }^{[1]}$. 直到 20 世纪 60 年代, Bondi等人 ${ }^{[2]}$ 和 Sachs ${ }^{[3]}$ 通过Bondi-Sachs理论框架解决 了这个理论问题. 最近, 人们还在这个框架下考察了 宇宙学常数的影响 ${ }^{[4,5]}$. Bondi-Sachs理论框架在定性层 面给出了引力波的描述方式. 为了满足引力波探测的 需要, 我们需要建立定量的引力波波源理论模型.

从 20 世纪 60 年代开始, 韦伯开创性地建立共振 棒型引力波探测器并宣称观测到了引力波, 但他的 结果没有被其他人证实. 始于 70 年代初, 人们提出利 用激光干涉来探测引力波的想法. 到 90 年代末, 以 LIGO为代表的激光干涉型探测器被建立起来. 对比 共振棒型探测器, 激光干涉型探测器不仅具有更高 的灵敏度, 其优越性主要还体现在宽频带这个特点
上. 具体地说, LIGO的敏感频带包括从几十赫兹到 上千赫兹，而共振棒的敏感频带是在约一千赫兹的 地方，宽度只有几个赫兹. 激光干涉仪的宽频带特点 使得在二战时期发展起来的雷达数据处理技术一 匹配滤波方法(matched filtering)可以被引人到引力 波数据处理中来 ${ }^{[6]}$. 该方法可以把完全埋在噪声中的 信号挖掘出来. 所以该方法可以在既定硬件灵敏度 的基础上很好地提高引力波探测能力. 但该方法实 施的前提条件是准确的引力波理论模型.

引力波探测完成了广义相对论实验检验的最后 一块拼图. 但引力波探测更为重要的是开启人类对 宇宙全新的观测方式一引力波天文学. 为了实现 引力波天文学, 人们需要完成从引力波实测数据到 波源性质的反演, 从引力波信号中分析出波源是什 么, 动力学演化过程, 其相关的参数是多少. 目前最 直接的波源反演方法是基于引力波理论模型，通过 
匹配滤波数据处理, 找出匹配得最好的理论波源以 及相关参数, 由此实现波源的反演.

在GW150914实验中, 人们就使用这个方法, 基 于有效单体数值相对论(EOBNR)理论模型反演出波 源是并合双黑洞, 同时还给出了双黑洞相应的质量、 自旋等参数信息.

为了建立引力波源理论模型, 我们需要针对特 定的现实引力波源求解爱因斯坦方程. 本文将针对 双星系统讨论爱因斯坦方程的求解和理论模型的建 立. 双星系统的演化过程可分为旋进(inspiral)、并合 (merger) 和铃振 (ringdown) 3 个阶段 ${ }^{[7]}$. 在旋进的早期, 双星间距较大, 引力相互作用较弱, 后牛顿近似适 用. 到旋进后期和并合期, 引力场极强、变化也极快, 现有的近似方法都失效, 数值相对论是目前唯一可 行的处理方法. 并合结束, 时空将逐渐演化到转动的 克尔黑洞状态. 这个铃振过程可以用克尔黑洞的微 扰来描述. 该微扰需要的克尔黑洞的质量和自旋信 息可以由数值相对论的计算提供. 本文将对后牛顿 近似方法、数值相对论方法和克尔黑洞微扰方法作一 个系统的介绍. 然后讨论综合 3 种方法得到的有效单 体数值相对论理论模型. 最后对双星系统引力波理 论模型作一个小结和展望.

\section{1 后牛顿近似模型}

二体问题在牛顿引力理论中是可积的. 但在广 义相对论中, 除了试验粒子的理想情况, 二体问题没 有严格的解析解. 因此, 二体以及多体问题, 即两个 及以上的引力相互作用的延展体的动力学问题, 是 广义相对论中非常重要的研究内容. 这一问题从爱 因斯坦提出他的引力理论后就很快得到关注. 爱因 斯坦、Droste、de Sitter等人做了前驱性的工作. 现在 熟知的描述 $N$ 个点质量粒子的运动学方程是所谓的 Einstein-Infeld-Hoffmann 方 程 ${ }^{[8]}$, 不过在此之前 Lorentz和Droste ${ }^{[9]}$ 也给出了类似的结果. 这些工作采 用了后牛顿(PN)近似方法, 在低速弱场的情形下有 效. Einstein-Infeld-Hoffmann方程就是一阶后牛顿 $\left(O\left(v^{2} / c^{2}\right)\right)$ 的多体运动方程. Hulse和Taylor发现脉冲 双星后, 一阶后牛顿的运动方程不能满足相对论效 应较强的双星系统的需要. 引力波探测热潮兴起后, 相对论性双星系统的旋进和并合过程的动力学和引 力波计算进一步提出了更高阶后牛顿展开的需求. 20 世纪 90 年代末到 21 世纪初, 研究人员将二体问题的
动力学方程扩展到 $3 \mathrm{PN}$ 水平, 并包含 $3.5 \mathrm{PN}$ 的辐射反 作用项, 目前已经有了 $4 \mathrm{PN}$ 的双星系统的运动学方 程 ${ }^{[10]}$. 二体问题的这些后牛顿动力学方程有两种形 式:一种称为哈密顿形式, 一种称为拉格朗日形式, 但二者并不等价. 对于特定的二体系统, 拉格朗日形 式的后牛顿运动方程会给出混沌轨道, 而哈密顿形 式则不会 ${ }^{[11]}$.

本文不对后牛顿的理论细节给出描述, 有兴趣 的读者可参阅文献 $[12,13]$. 后牛顿近似方法处理双 星系统的理论框架包括双星动力学和引力波波形两 大组成部分. 为了得到引力波理论模型的显表达式, 需要求解双星动力学方程, 然后把解代人波形理论 部分得到显表达式. 一般情况下, 后牛顿近似的动力 学方程是一个高度非线性的常微分方程组, 很难解 析求解. 人们常常采用数值求解的方式. 直接在时域 求解的理论模型包括 TaylorT2和TaylorT4等 ${ }^{[14]}$. 通过 稳相近似技术, 人们还可以把后牛顿方程约化为频 域问题, 甚至得到近似的解析表达式. 这样模型的典 型代表是 TaylorF2模型. 考虑到黑洞自旋对双星动力 学的影响, 特别是轨道进动的影响, TaylorF2模型被 完善为单进动模型 ${ }^{[15]}$ 或者双进动模型 ${ }^{[16]}$. 考虑椭圆 轨道的双星系统时, TaylorT2模型被替代为 $\mathrm{X}$ 模型 ${ }^{[17]}$. 把 TaylorF2模型推广到椭圆轨道双星系统的理论模 型包括后圆(Post Circular, PC) 模型 ${ }^{[18]}$ 和加强的后圆 (Enhanced Post Circular, EPC)模型 ${ }^{[19,20]}$.

\section{2 数值相对论}

使用数值计算方法来求解爱因斯坦方程就是数 值相对论所研究的内容. 在双星演化的旋进后期以 及并合期, 目前只有数值相对论能处理引力波建模 的问题. 由于数值相对论是对爱因斯坦方程不做任 何解析近似的数值求解, 这个特点使得数值相对论 成为引力波源理论建模过程中的万能工具. 但爱因 斯坦方程的微分同胚性质给数值计算带来非常特殊 的困难. 数值相对论的研究开始于 20 世纪 60 年代 ${ }^{[21]}$, 但数值计算的不稳定使得当时的计算程序在演化几 十步后就崩溃掉. 到 20 世纪90年代, 在LIGO对理论 模型的强烈需求背景下, 美国的十几所高校和科研 单位联合开展了双黑洞大挑战计划(the binary black hole grand challenge project). 但数值计算的稳定性问 题没得到实质性解决. 到2000年左右, 美国加州理工 学院教授、LIGO的领导人之一Kip Thorn就曾经悲观 
地说, “很可能引力波探测的实现比数值相对论的突 破还要实现得早”. 出人意料的是, 在 2005 年稳定性 问题首先被Pretorius ${ }^{[22]}$ 突破。在接下来的 2006 年, Baker ${ }^{[23]}$ 和Campanelli ${ }^{[24]}$ 两个小组独立地在稳定性问 题上也得到了突破. 到2010年, 全世界有包括美国普 林斯顿大学、美国加州理工学院、德国Jena大学、德 国马普所和中国科学院数学与系统科学研究院等十 来个数值相对论小组突破稳定性问题, 独立地建立 起数值相对论软件, 可以实现LIGO精度要求的数值 计算.

值得指出的是, 在数值相对论稳定数值计算的 各种计算方法中, 哪些步骤是实现稳定计算的必要 和充分条件到现在还是一个公开的问题. 在偏微分 方程理论层面, 人们目前还只会基于线性化爱因斯 坦方程的双曲性分析 ${ }^{[25]}$. 从实际操作的角度分析, 在Pretorius 2005年的突破中, 爱因斯坦方程的计算 方程形式和自适应网格细化计算方法是最为关键的 两个要素. 在目前的数值相对论计算中包括BSSN方 程形式和广义调和坐标方程形式 ${ }^{[26]}$. 自适应网格细 化是处理多尺度计算问题非常有效的计算方法. 目 前世界上专门针对爱因斯坦方程开发的并行自适应 网格细化大科学计算平台主要包括Bruegmann开发 的BAM, 曹周键开发的AMSS-NCKU ${ }^{[27]}$, Pretorius开 发的PAMR, Schnetter开发的Carpet等.

谱方法、差分方法和有限元方法是偏微分方程数 值计算的三大类方法. 绝大多数数值相对论小组使 用差分方法. 加州理工学院的 SpEC软件使用谱方法. 有限元方法在数值相对论中应用目前还不多 ${ }^{[28]}$. 谱 方法由于其指数收玫性而具有好的计算效率. 但其 全局数据交换的特点限制其并行计算的能力. 差分 法结合区域分解算法可以达到很好的并行计算效率. 为了处理天体物理中的多尺度特点, 多数据层结构 的网格细化在差分法中不可或缺. 但这样的处理方 法使得单个数据层的网格数限制了并行计算的最多 核心数, 从而限制了强并行可扩展性. 与此对比, 有 限元方法可以通过单元内使用谱方法, 单元与单元 间使用类似于差分方法的处理方式. 由此可以结合 谱方法的指数收玫性和差分法的高并行可扩展性. 同时, 由于有限元中的网格细化没有数据层分别, 所 有的单元统一在同一个模式下处理. 所以理论上预 期有限元计算爱因斯坦方程可以达到好的强并行可 扩展性. 但爱因斯坦方程的弱方程形式很难构造, 其
大规模科学计算也很难实现.

在计算精度方面, 谱方法是目前精度最高的. 但 谱方法在处理物质场与爱因斯坦方程耦合时遇到稳 定性困难限制了谱方法在数值相对论中的进一步发 展. 有限差分方法的鲁棒性远远超过谱方法. 目前差

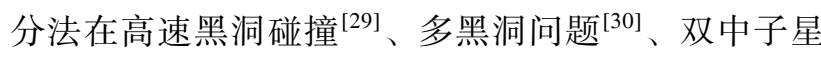
并合 ${ }^{[31]}$ 、修改引力理论 ${ }^{[32]}$ 、高维引力理论 ${ }^{[33]}$ 、负质 量黑洞 ${ }^{[34]}$ 等问题上都得到广泛应用. 在计算精度问 题上, 差分方法近年来也得到大的发展. 德国Jena数 值相对论小组和中国科学院数学与系统科学研究院 小组合作发展出Z4c方程形式 ${ }^{[35,36],}$ 德国马普所独立

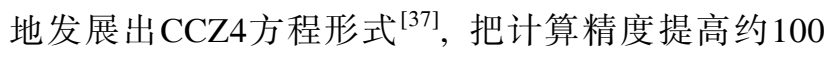
倍. 在 Z4c 方程形式基础上, 德国Jena数值相对论小 组和中国科学院数学与系统科学研究院小组发展出 保约束边界条件进一步提高精度约 10 倍 ${ }^{[31]}$. 在高自 旋双黑洞问题上, 中国科学院数学与系统科学研究 院与台湾成功大学联合小组改进自旋角动量的计算 精度约7倍 ${ }^{[38]}$.

爱因斯坦方程的数值计算是典型的计算密集型 问题, 如果能使用GPU实现硬件加速将大大提高数 值计算效率. 但如何在不影响并行自适应网格细化 数据层间以及不同 $\mathrm{CPU}$ 间数据交换的前提下协调爱 因斯坦方程计算的庞大内存需求和GPU小硬件内存 之间的矛盾是该问题的本质困难. 中国科学院数学 与系统科学研究院与清华大学联合小组设计出初步 的专门针对爱因斯坦方程的计算一通讯重叠算法, 实现了约 10 倍GPU硬件计算加速. 同时, 清华大学的 都志辉教授在美国Titan超级计算机上的测试表明直 到至少 1024 个计算节点 (合为 16384 个计算核心) 和 1024个GPU, GPU版本的AMSS-NCKU软件还保持比 较好的并行可扩展性. 这里的并行可扩展性是衡量 一个并行计算软件整体性能的指标. 该指标是指当 使用 $N$ 个计算核心进行计算时其计算速度能否能达 到 1 个计算核心的大致 $N$ 倍 (理想的并行可扩展性). 但对比 GPU在引力波数据处理中 120 倍硬件加速 ${ }^{[39]}$, 我们预期该问题还有进一步的发展空间.

双黑洞系统对应真空爱因斯坦方程. 而真空爱 因斯坦方程在几何单位制下只涉及一个基本量 ${ }^{[40]}$. 不失一般性, 我们可以选取质量作为基本量. 真空爱 因斯坦方程相对于这个基本量是标度不变的. 因此, 数值相对论在处理双黑洞问题时常常选取两个黑洞 的总质量为 1 . 在回到实际的引力波问题时, 把所得 
结果按实际的双黑洞质量按量纲关系做适当的标度 变换即可得到所需结果. 比如说对应地面引力波探 测器, 用约太阳质量做回标度变换; 对应空间引力波 探测计划, 用约百万太阳质量做回标度变换. 而实际 上数值计算的结果是同一个. 所以在数值研究双黑 洞系统时我们只需要关心黑洞的质量比, 两个黑洞分 别的自旋, 初始时刻两个黑洞的间距以及绕转轨道离 心率. 典型地, 使用256个计算核心, 计算一个双黑洞 系统演化 1000 个时间单位约需要 10 天的墙钟时间. 对 于有物质场耦合的问题, 如双中子星问题, 上述的标 度不变性不再存在. 具体波源需要单独的计算.

对于沿圆轨道绕转的双黑洞系统, 文献中的讨 论已经比较多 ${ }^{[26]}$. 这里以极端椭圆轨道的双黑洞系 统为例来展示双黑洞演化的数值计算结果(图 1). 这 里使用了外尔张量的方法来从数值计算所得的度规 系数数值解中提取引力波信息. 这种方法可以利用 外尔张量自旋权重为 2 的特点过滤掉一些数值计算的 误差 ${ }^{[41]}$. 极端椭圆轨道的双黑洞沿直线对头撞到一 起然后并合. 与相互旋绕的双黑洞系统不同, 如图 1(a)所示, 引力波呈现球形分布, 而不是绕转情形的
螺旋状分布. 这样的分布导致引力波功率出现如图 1(c)所示的峰谷相间的行为, 也导致图 1(d)中的平台 行为. 在图1(b)中画出不同空间位置所给出的引力波 波形. 在比较近的地方, 我们能看到由于近场效应导 致的波动行为. 这些行为受到规范自由度等的影响, 没有很好的物理意义. 只有在测量位置比较远时(如 $r=50)$, 引力波真正进人波动区, 从时空的角度说叫 作渐近平直区, 这里的波形才有明确的物理意义.

\section{3 黑洞微扰模型}

因为小质量天体的引力作用可以看作对大质量 黑洞引力场的微扰, 黑洞微扰方法适合计算双星质 量相差较大的旋进系统的引力波. 双星并合后铃振 阶段可以逆着时间看作是最后克尔黑洞的微扰，所 以铃振阶段的引力波也可以使用黑洞微扰模型来描 述. 开创性黑洞微扰理论的研究工作有 Regge, Wheeler ${ }^{[42]}$ 和Zerilli ${ }^{[43]}$ 给出的史瓦西黑洞的度规微扰 方法, Teukolsky等人 ${ }^{[44,45]}$ 发展的克尔黑洞的曲率微 扰方法. 前者称为Regge-Wheeler-Zerilli方程，后者 称为Teukolsky方程. 对于史瓦西黑洞, Regge-Wheeler-
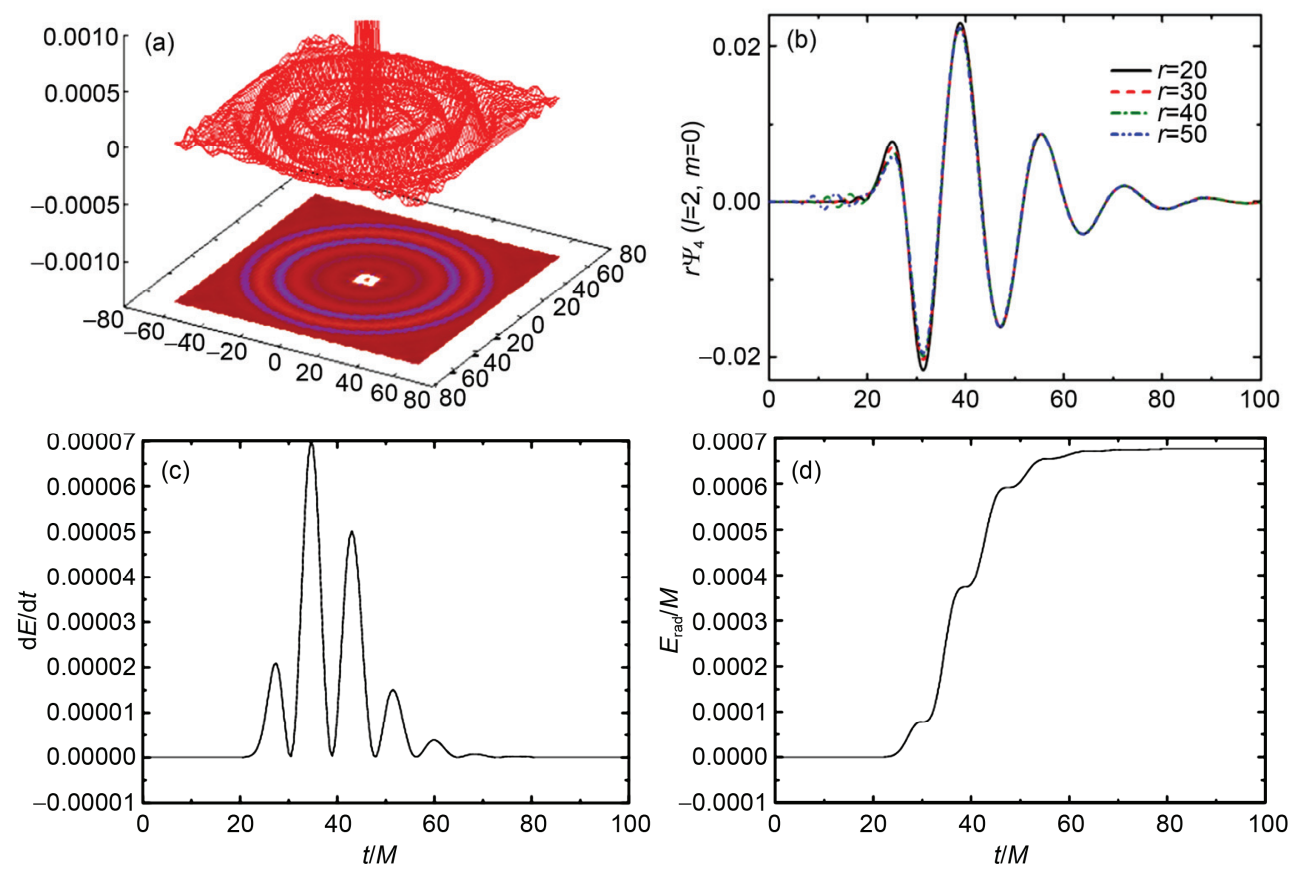

图 1 (网络版彩色)极端椭圆轨道双黑洞系统的数值计算结果. (a) 引力波的空间分布情况; (b) 引力波波形; (c) 引力波功率随时间变化; (d) 引 力波所辐射能量的随时间累积情况

Figure 1 (Color online) Numerical calculation of tow head on collision black holes. (a) The space distribution of gravitational wave; (b) the gravitational wave form; (c) the power of the gravitational wave respect to time; (d) accumenated energy carried by the gravitational wave respect to time 
Zerilli方法和Teukolsky方法是等价的 ${ }^{[46]}$. 但对于克 尔黑洞Teukolsky方程对应什么样的度规微扰目前还 是一个公开的问题. 20 世纪70年代初, 有学者已经开 始用Regge-Wheeler-Zerilli方程来研究试验粒子落人 黑洞的引力波 ${ }^{[47 \sim 49]}$. 由于Teukolsky方程包含黑洞自 旋, 适用性更广, 近年来运用其来计算引力波的研究 工作很多. 这里主要介绍Teukolsky方程在极端质量 比双星系统引力波计算中的研究工作. 描述双星并 合后铃振阶段的准正则模式理论可以参考文献 [46] 中的详细描述.

解Teukolsky方程可以用后牛顿展开的分析方法 也可以直接数值求解. 前者主要由Mano, Suzuki以及 Takasugi等人 ${ }^{[50,51]}$ 发展的超几何函数和Coulomb波函 数来逼近Teukolsky方程齐次形式的解. 后来Fujita ${ }^{[52]}$ 运用这些分析解, 通过后牛顿展开, 来计算极端质量 比圆轨道旋进系统的引力波波形和能流, 目前对史 瓦西黑洞已经可以展开到22PN精度, 对克尔黑洞达 到11PN精度 ${ }^{[33]}$. 不过这些分析结果的精度可能仍然 达不到极端质量比引力波模板的要求 ${ }^{[54]}$.

Teukolsky 方程的数值计算方法分为频域 (frequency-domain)和时域(time-domain)两种方法. 前者 通过分离变量和傅里叶展开将原始的偏微分分解成 两个常微分方程 ${ }^{[44]}$, 然后数值求解. 其中径向方程 的计算必须要先变换到 Sasaki-Nakamura方程 ${ }^{[55]}$. 不 过Teukolsky方程只能提供能流和引力波, 为了计算 试验粒子旋进的过程, Hughes等人 ${ }^{[56 ~ 60]}$ 用绝热收缩 的测地线轨道来近似表示轨道旋进的过程, 并取得 了成功, 成为极端质量比旋进系统轨道演化和引力 波计算的重要方法. 有别于一般的差分数值方法, Fujita和Tagoshi用齐次方程的超几何函数和Coulomb 波函数展开, 给出了一种快速高精度计算径向方程 的数值方法 ${ }^{[60,61]}$. 目前该方法已经开始替代差分方 法成为Teukolsky方程频域数值计算的主要方法.

时域的数值方法是直接求解通过坐标变换并引 人轴对称性后得到的一组 $2+1$ 维偏微分方程. 目前主 要采取的是差分方法求解, 但也有学者用有限元方 法 $^{[61]}$. 早期的计算程序由Krivan等人 ${ }^{[62]}$, Lopez-Aleman 等人 ${ }^{[63]}$ 完成, 用于计算圆轨道的试验粒子绕克尔黑 洞的引力辐射, 后来 Khanna小组 ${ }^{[64]}$ 将其推广到非圆 轨道. 2011年, Zenginŏglu和Khanna ${ }^{[65]}$ 使用双曲面紧 致化(hyperboloidal compactification)技术, 使得可以 在无穷远处提取引力波波形, 提高了计算精度. 韩文
标等人 ${ }^{[66 ~ 69]}$ 开发了 Teukolsky方程频域和时域的计算 程序, 并用等效单体方法来给出双星的轨道运动. 尽 管微扰方法的数值计算所需时间小于数值相对论, 但是由于极端质量比旋进系统的旋进过程可以长达 数年, 如何提高 Teukolsky方程的计算效率, 特别是 如何快速计算对带有偏心率和倾角的一般轨道的引 力波, 仍是一个挑战.

\section{4 等效单体数值相对论理论模型}

在2000年前后Buonanno和Damour把二体问题化 为一个等价的单体问题, 提出了等效单体(effective onebody, EOB)方法 ${ }^{[70,71]}$, 目的是对双星合并的整个 完整过程(包括早期的旋进、突降、并合以及铃振)给 出解析的描述(注意, 这里“解析”的含义是指显式的 二体运动学方程和引力波波形表达式, 完成最终的 计算可能还需要用数值积分器来解常微分方程组). 在数值相对论取得突破性结果的前 5 年, EOB方法就 给出了双黑洞合并动力学过程和引力波辐射的预 言 $^{[72]}$ : (1) 从旋进到突降阶段是平滑的过渡; (2) 在 双黑洞并合时, 引力波出现剧烈变化强度达到峰值, 之后发生铃振; (3) 估计了辐射总能量以及最终黑洞 的自旋. $\mathrm{EOB}$ 的成功使得在接下来的 10 多年里快速发

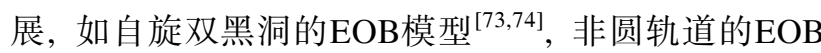
动力学 ${ }^{[75]}$, $4 \mathrm{PN}$ 推广 ${ }^{[76]}$, 运用到小质量比情形 ${ }^{[77,78]}$, 任意质量比和自旋的 $\mathrm{EOB}$ 模型 ${ }^{[79]}$, 潮汐效应的考 虑 $^{[80 ~ 82]}$, 以及利用引力自力方法来改进 $\mathrm{EOB}^{[83]}$ 等.

下面简单地介绍 $\mathrm{EOB}$ 方法的核心思想和大致计 算过程, 详细的过程请参阅Damour的综述 ${ }^{[72]}$. 完整 的EOB模型包含 3 个独立又相互影响的部分: 描述双 星轨道动力学中的守恒部分, 即哈密顿量; 引力波辐 射反作用的表达式; 合并双星引力波波形的表达式. 这3个部分都来自于多年发展起来的高阶后牛顿展开 形式. 不过, 关键的一点是EOB不使用传统PN近似 的泰勒展开形式(即 $a_{0}+a_{1} \frac{v}{c}+a_{2} \frac{v^{2}}{c^{2}}+\cdots$ ), 而是使用 重求和(resum)形式. 上述 3 个部分的重求和方法各自 不同, 这里不再详述.

先介绍二体动力学中的守恒部分. 在牛顿力学 中, 二体问题既可以等价地用一个质量为约化质量 的“试验粒子”绕“中心质量体” $M$ ( $M$ 为二体总质量)的 轨道运动. $\mathrm{EOB}$ 是这一牛顿情形的广义相对论推广, 即找到一个等效的外部时空度规, 该度规是坐标、总 
质量以及对称质量比的函数. 质量为约化质量的试 验粒子在这样的等效时空度规场中作测地线运动. 这种处理等价于传统的二体相对运动的后牛顿展开. EOB形式的哈密顿量写成如下形式:

$$
H_{\mathrm{EOB}}=M \sqrt{1+2 v\left(\frac{H_{\mathrm{eff}}}{\mu-1}\right)},
$$

其中 $H_{\mathrm{EOB}}$ 称为真实 $\mathrm{EOB}$ 哈密顿量, $v$ 为对称质量比, $\mu$ 为约化质量. $H_{\text {eff }}$ 为等效哈密顿量, 在没有自旋的情 况, 它就是质量为 $\mu$ 试验粒子在等效度规场运动的哈 密顿量. 这样就能写出动力学方程:

$$
\dot{r}=\frac{\partial H_{\mathrm{EOB}}}{\partial p}, \dot{p}=-\frac{\partial H_{\mathrm{EOB}}}{\partial r}+\boldsymbol{F},
$$

其中变量上的点表示对时间的微分, $F$ 表示引力波 的辐射反作用力, 此项的存在导致二体系统的能量 和角动量不再守恒. 如何计算辐射反作用力, 同样来 自于重求和后牛顿展开形式, 初始的想法来自于对 后牛顿的能流函数采用Pade重求和技术 ${ }^{[84]}$. 后来 Damour和Nagar ${ }^{[85,86]}$ 又引进了对辐射反作用(包括波 形)新的更精确的重求和方法. 现在, 普遍使用的辐 射反作用力为 ${ }^{[87]}$

$$
\mathcal{F}=\frac{1}{\Omega|\boldsymbol{r} \times \boldsymbol{p}|} \frac{\mathrm{d} E}{\mathrm{~d} t} \boldsymbol{p},
$$

其中 $\Omega$ 表示轨道角频率, $\mathrm{d} E / \mathrm{d} t$ 是引力波的能流

$$
\frac{\mathrm{d} E}{\mathrm{~d} t}=\frac{\Omega^{2}}{8 \pi} \sum_{\ell=2}^{8} \sum_{m=0}^{\ell} m^{2}\left|\frac{R}{M} h_{\ell m}\right|,
$$

其中 $h_{l m}$ 正是引力波的波形. $\mathrm{EOB}$ 方法本质还是后牛 顿近似, 无法给出并合后的铃振部分的波形. 因此在 $\mathrm{EOB}$ 模型中, 引力波波形的计算由两部分拼接而 成 ${ }^{[72]}$. 一部分是旋进和突降阶段的引力波形, 由 EOB方法引人一些需要用数值相对论和黑洞微扰方 法的结果进行校准的自由参数并通过重求和技术给 出; 第二部分并合至铃振部分的引力波用黑洞微扰 的准正则模给出. 两部分在双黑洞并合的时刻, 按照 $\mathrm{EOB}$ 的定义, 即为轨道角动量最大的时刻, 光滑地连 接起来. 绕转和突降阶段的引力波波形无需连接, 因 为这两者之间过渡非常模糊,

$$
h_{\ell m}^{\text {insp-plunge }}=h_{\ell m}^{\mathrm{F}} N_{\ell m} .
$$

$N_{l m}$ 是非准圆轨道的修正, 是由于引力波辐射其 轨道偏离圆轨道产生的. 而重求和的后牛顿波形为

$$
h_{\ell m}^{\mathrm{F}}=h_{\ell m}^{(N, \varepsilon)} \hat{S}_{\text {eff }}^{(\varepsilon)} T_{\ell m} \mathrm{e}^{\mathrm{i} \delta_{\ell m}}\left(\rho_{\ell m}\right)^{\ell} .
$$

可以看到, 波形分解成了多个因子, 称为因子化 (factorized)形式. 其中第一项为牛顿项，第二项为源 项, 第三项称为尾项, 第四项来自于相位偏移, 最后 一项正是重求和的后牛顿波形. 这些项中包含了一 些自由参数, 可以利用数值相对论以及极端质量比 情形下的微扰方法(包括引力自力方法)的结果来进 行校准. 这正是EOB方法比一般后牛顿方法更加精 确的原因. 详细的表达式可见本文列举的 $E O B$ 相关 文献.

EOB方法的成功, 使得很多研究者用其开发引 力波探测所需的模版, 如Pan和Yunes等人 ${ }^{[87 ~ 99]}$ 做了 大量的工作, 逐渐建立起了等效单体数值相对论 (EOBNR)模型. EOBNR模型发展的早期使用了美国 国家航空航天局(NASA)数值相对论小组和德国马普 所数值相对论小组的计算结果. 后来潘奕在精细化 EOBNR模型过程中主要使用美国加州理工-康奈尔 大学联合数值相对论小组的计算结果. 在 2012年中 国科学院数学与系统科学研究院数值相对论小组和 潘奕合作，对比AMSS-NCKU计算结果和EOBNR模 型结果(图2). 不同数值相对论小组使用的爱因斯坦 方程形式、坐标条件、计算方法和并行计算数据结构 框架等都不相同. 在当时引力波没有被探测到, 爱因 斯坦方程真实解无从查证的情况下, 这一结果为潘 奕发展EOBNR模型提供了启示、增添了信心. EOB动 力学部分可以独立出来和其他方法得到的波形(或者 包括辐射反作用项)结合, 提高动力学过程以及波形 的精度. 如利用EOB方法给出极端质量比的动力学轨 道, 用黑洞微扰方法给出数值波形 ${ }^{[100,101]}$; 韩文标和 曹周键只采用EOB的守恒动力学部分, 辐射反作用和 波形全部由黑洞微扰的数值结果给出, 提高了辐射反 作用部分的精度. 这一模式后来也得到了其他学者的 应用 ${ }^{[102]}$. 最近, 韩文标 ${ }^{[67]}$ 又将其推广到带有偏心率 轨道的情形, 后来给出了更加高效的“ET”模型, 可以 快速且高精度的计算极端质量比的波形 ${ }^{[68]}$. EOBNR模 型未来将得到更大关注和发展, 特别是一般形状轨道 的推广, 将是未来重要的研究方向.

\section{5 结论}

引力波理论模型在引力波信号探测和波源反演 中都扮演着重要的甚至是不可或缺的角色. 在 GW150914的数据处理中, 这个重要性得到了很好的 体现. GW150914探测结果是实验技术重大进步的胜 利, 也是引力波理论模型研究近年来一系列重大进 

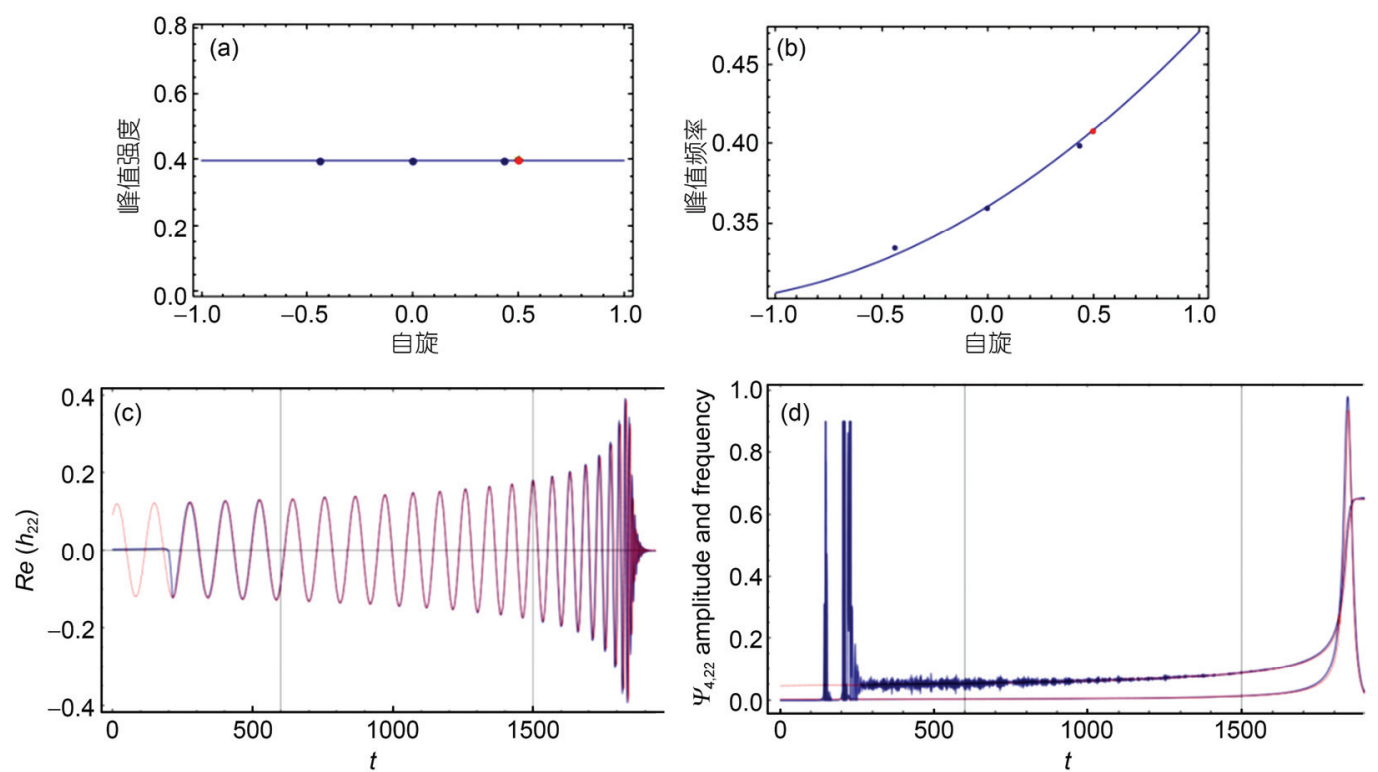

图 22012 年中国科学院数学与系统科学研究院数值相对论小组同潘奕的合作结果. 该图由潘奕绘制得到. 横轴的自旋指初始双黑洞的自旋. (a) 双黑洞系统所辐射引力波在整个并合过程中的最大值; (b) 是在整个并合过程中引力波频率的最大值; (c) 引力波随时间的波形; (d) 引力 波的强度和频率随时间的关系. 其中红线对应EOBNR的结果, 蓝线对应AMSS-NCKU的计算结果. 在(a)和(b)中, 蓝点为加州理工学院数值相 对论计算结果, 红点是AMSS-NCKU计算结果, 蓝色的线是EOBNR的结果

Figure 2 Calculation result got by our numerical relativity group and PAN Yi. This figure was made by PAN Yi in 2012. (a) The peak amplitude of the gravitational wave in the whole inspiral-merger-ringdown process of binary black hole; (b) the peak frequency of the gravitational wave during the whole process; (c) the gravitational wave form respect to time; (d) the amplitude and the frequency of the gravitational wave respect to time, where the redlines corresponding to EOBNR and the blue line corresponding to the result of AMSS-NCKU code. In (a) and (b), the blue points are the calculation results got by SpEC code; the red points are got by AMSS-NCKU code; and the blue lines are the result of EOBNR model. The spin corresponding to the $x$-axis means the spin of the initial two black holes

展的结晶. 随着引力波天文学的逐渐展开, 引力波理 论模型的研究在基本物理理论和天文观测实际需要 双重意义上都变得越来越重要. 本文着眼于并合双 星系统, 对相关的引力波建模方法和理论模型作了 粗略描述. 本文只描述了与实际物理系统参数有直 接对应的理论模型. 与此相关的为了加速引力波数
据处理而发展起来的唯象模型, 如 BCV 模型 ${ }^{[103]}$ IMRPHENOM模型 ${ }^{[104]}$ 等, 本文没有提及. 感兴趣的 读者可以参阅相关文献. 本文所描述的若干方法, 如 后牛顿近似方法和数值相对论方法等，除了应用到 本文关心的并合双星系统外, 还可以在其他引力波 源建模问题上得到应用, 这里就不再赘述.

\section{参考文献}

1 Kennefick D. Traveling at the Speed of Thought: Einstein and the Quest for Gravitational Waves. Princeton: Princeton University Press, 2007

2 Bondi H, Van der Burg M, Metzner A. Gravitational waves in general relativity. VII. Waves from axi-symmetric isolated systems. Proc R Soc Lond A Math Phys Sci, 1962, 269: 21-52

3 Sachs R K. Gravitational waves in general relativity. VIII. Waves in asymptotically flat space-time. Proc R Soc Lond A Math Phys Sci, 1962, 270: 103-126

4 He X, Cao Z. New Bondi-type outgoing boundary condition for the Einstein equations with cosmological constant. Int J Mod Phys D, 2015, 24: 1550081

5 Ashtekar A, Bonga B, Kesavan A. Gravitational waves from isolated systems: Surprising consequences of a positive cosmological constant. Phys Rev Lett, 2016, 116: 051101 
6 Creighton J, Anderson W. Gravitational-Wave Physics and Astronomy. Weinheim: Wiley-VCH Press, 2011

7 Cao Z. Gravitational wave detection and gravitational wave astronomy (in Chinese). Modern Phys, 2015, 27: 40-42 [曹周键. 引力波探 测和引力波天文学. 现代物理知识, 2015, 27: 40-42]

8 Einstein A, Infeld L, Hoffmann B. The gravitational equations and the problem of motion. Anna Math, 1938, 39: 65-100

9 Lorentz H A, Droste J. The Motion of A System of Bodies Under the Influence of Their Mutual Attraction, According to Einstein's Theory. Collected Papers. Netherlands: Springer, 1937. 330-355

10 Blanchet L. Gravitational radiation from post-Newtonian sources and inspiralling compact binaries. Liv Rev Rel, 2014, 17: 1-101

11 Wu X, Mei L, Huang G, et al. Analytical and numerical studies on differences between Lagrangian and Hamiltonian approaches at the same post-Newtonian order. Phys Rev D, 2015, 91: 024042

12 Xu C M, Wu X J. General Relativity and Modern Cosmology (in Chinese). Nanjing: Nanjing Normal University Press, 1999 [须重明, 吴 雪君. 广义相对论与现代宇宙学. 南京: 南京师范大学出版社, 1999]

13 Blanchet L, Damour T. Post-Newtonian generation of gravitational waves. Annales de l'IHP Phys Théorique, 1989, 50: 377-408

14 Buonanno A, Iyer B, Ochsner E, et al. Comparison of post-Newtonian templates for compact binary inspiral signals in gravitational-wave detectors. Phys Rev D, 2009, 80: 084043

15 Lundgren A, Shaughnessy R. Single-spin precessing gravitational waveform in closed form. Phys Rev D, 2014, 89: 044021

16 Chatziioannou K, Cornish N, Klein A, et al. Detection and parameter estimation of gravitational waves from compact binary inspirals with analytical double-precessing templates. Phys Rev D, 2014, 89: 104023

17 Hinder I, Herrmann F, Laguna P, et al. Comparisons of eccentric binary black hole simulations with post-Newtonian models. Phys Rev D, 2010, 82: 024033

18 Yunes N, Arun K, Berti E, et al. Post-circular expansion of eccentric binary inspirals: Fourier-domain waveforms in the stationary phase approximation. Phys Rev D, 2009, 80: 084001

19 Huerta E, Kumar P, McWilliams S, et al. Accurate and efficient waveforms for compact binaries on eccentric orbits. Phys Rev D, 2014, 90: 084016

20 Sun B, Cao Z, Wang Y, et al. Parameter estimation of eccentric inspiraling compact binaries using an enhanced post circular model for ground-based detectors. Phys Rev D, 2015, 92: 044034

21 Hahn S, Lindquist R. The two body problem in geometrodynamics. Ann Phys, 1964, 29: 304-331

22 Pretorius F. Evolution of binary black-hole spacetimes. Phys Rev Lett, 2005, 95: 121101

23 Baker J, Centrella J, Choi D, et al. Gravitational-wave extraction from an inspiraling configuration of merging black holes. Phys Rev Lett, 2006, 96: 111102

24 Campanelli M, Lousto C, Marronetti P, et al. Accurate evolutions of orbiting black-hole binaries without excision. Phys Rev Lett, 2006, 96: 111101

25 Hilditch D. An introduction to well-posedness and free-evolution. Int J Mod Phys A, 2013, 28: 1340015

26 Baumgarte T, Shapiro S. Numerical Relativity: Solving Einstein's Equations on the Computer. Cambridge: Cambridge University Press, 2010

27 Cao Z J. The relativistic celestial simulation software based on Einstein equations (in Chinese). China Patent. 2015SR047789, 2015 [曹 周键. 基于爱因斯坦方程的相对论性天体模拟软件. 中国专利. 2015SR047789, 2015]

28 Cao Z. Binary black hole simulation with an adaptive finite element method: Solving the Einstein constraint equations. Phys Rev D, 2015, 91: 044033

29 Sperhake U, Cardoso V, Pretorius F, et al. High-energy collision of two black holes. Phys Rev Lett, 2008, 101: 161101

30 Galaviz P, Bruegmann B, Cao Z. Numerical evolution of multiple black holes with accurate initial data. Phys Rev D, 2010, 82: 024005

31 Hilditch D, Bernuzzi S, Thierfelder M, et al. Compact binary evolutions with the Z4c formulation. Phys Rev D, 2013, 88: 084057

32 Cao Z, Galaviz P, Li L. Binary black hole mergers in f(R) theory. Phys Rev D, 2013, 87: 104029

33 Zilhao M, Witek H, Sperhake U, et al. Numerical relativity for D dimensional axially symmetric space-times: Formalism and code tests. Phys Rev D, 2010, 81: 084052

34 Cao Z. Numerical study of the interaction between positive and negative mass objects in general relativity. Int J Mod Phys D, 2012, 21: 1250061

35 Bernuzzi S, Hilditch D. Constraint violation in free evolution schemes: Comparing the BSSNOK formulation with a conformal decomposition of the Z4 formulation. Phys Rev D, 2010, 81: 084003

36 Cao Z, Hilditch D. Numerical stability of the Z4c formulation of general relativity. Phys Rev D, 2012, 85: 124032

37 Alic D, Kastaun D, Rezzolla L. Constraint damping of the conformal and covariant formulation of the Z4 system in simulations of binary neutron stars. Phys Rev D, 2013, 88: 064049

38 Yo H, Cao Z, Lin C, et al. Improved fast-rotating black hole evolution simulations with modified Baumgarte-Shapiro-Shibata-Nakamura formulation. Phys Rev D, 2015, 92: 024034

39 Liu Y, Du Z, Chung S, et al. GPU-accelerated low-latency real-time searches for gravitational waves from compact binary coalescence. Class Quantum Grav, 2012, 29: 235018 
40 Liang C. The Introduction to Differential Geometry and the General Relativity (in Chinese). Beijing: Beijing Normal University Press, 2000 [梁灿涁. 微分几何人门与广义相对论. 北京：北京师范大学出版社, 2000]

41 Bai S, Cao Z, Han W, et al. From binary black hole simulation to triple black hole simulation. J Phys-Conf Ser, 2011, $330: 012016$

42 Regge T, Wheeler J. Stability of a Schwarzschild singularity. Phys Rev, 1957, 108: 1063-1069

43 Zerilli F. Gravitational field of a particle falling in a Schwarzschild geometry analyzed in tensor harmonics. Phys Rev D, 1970, 2: 2141-2151

44 Teukolsky S. Perturbations of a rotating black hole. I. Fundamental equations for gravitational electromagnetic, and neutrino-field perturbations. Astrophys J, 1973, 185: 635-648

45 Teukolsky S, Press W. Perturbations of a rotating black hole. III. Interaction of the hole with gravitational and electromagnetic radiation. Astrophys J, 1974, 193: 443-461

46 Chandrasekhar S. The Mathematical Theory of Black Holes. New York: Oxford University Press, 1992

47 Davis M, Ruffini R, Tiomno J. Pulses of gravitational radiation of a particle falling radially into a schwarzschild black hole. Phys Rev D, 1972, 5: 2932-2945

48 Ruffini R. Gravitational radiation from a mass projected into a schwarzschild black hole. Phys Rev D, 1973, 7: 972-981

49 Fujita R, Tagoshi H. New numerical methods to evaluate homogeneous solutions of the teukolsky equation. Prog Theor Phys, 2004, 112: 415-450

50 Mano S, Suzuki H, Takasugi E. Post-Newtonian expansion of gravitational waves from a particle in circular orbits around a rotating black hole: Effects of black hole absorption. Prog Theor Phys, 1997, 98: 829-850

51 Sasaki M, Tagoshi M. Analytic black hole perturbation approach to gravitational radiation. Liv Rev Rel, 2003, 6: 1-125

52 Fujita R. Gravitational waves from a particle in circular orbits around a Schwarzschild black hole to the 22nd post-Newtonian order. Prog Theor Phys, 2012, 128: 971-1001

53 Fujita R. Gravitational waves from a particle in circular orbits around a rotating black hole to the 11th post-Newtonian order. Prog Theor Exp Phys, 2015, 3: 033E01

54 Sago N, Fujita R, Nakano H. Accuracy of the post-Newtonian approximation for extreme-mass ratio inspirals from black-hole perturbation approach. 2016, arXiv:1601.02174

55 Sasaki M, Nakamura T. Gravitational radiation from a Kerr black hole. I. Formulation and a method for numerical analysis. Prog Theor Phys, 1982, 67: 1788-1821

56 Hughes S. Evolution of circular, nonequatorial orbits of Kerr black holes due to gravitational-wave emission. Phys Rev D, 2000, 61: 084004

57 Hughes S. Evolution of circular, nonequatorial orbits of Kerr black holes due to gravitational-wave emission. II. Inspiral trajectories and gravitational waveforms. Phys Rev D, 2001, 64: 064004

58 Glampedakis K, Kennefick D. Zoom and whirl: Eccentric equatorial orbits around spinning black holes and their evolution under gravitational radiation reaction. Phys Rev D, 2002, 66: 044002

59 Hughes S, Drasco S, Flanagan E, et al. Gravitational radiation reaction and inspiral waveforms in the adiabatic limit. Phys Rev Lett, 2005, 94: 221101

60 Drasco S, Hughes S. Gravitational wave snapshots of generic extreme mass ratio inspirals. Phys Rev D, 2006, 73: 024027

61 Sopuerta C, Laguna P. Finite element computation of the gravitational radiation emitted by a pointlike object orbiting a nonrotating black hole. Phys Rev D, 2006, 73: 044028

62 Krivan W, Laguna P, Papadopoulos P, et al. Dynamics of perturbations of rotating black holes. Phys Rev D, 1997, 56: 3395-3404

63 Lopez-Aleman R, Khanna G, Pullin J. Perturbative evolution of particle orbits around Kerr black holes: Time-domain calculation. Class Quantum Grav, 2003, 20: 3259-3268

64 Sundararajan P, Khanna G, Hughes S. Towards adiabatic waveforms for inspiral into Kerr black holes: A new model of the source for the time domain perturbation equation. Phys Rev D, 2007, 76: 104005

65 Zenginoglu A, Khanna G. Null infinity waveforms from extreme-mass-ratio inspirals in Kerr spacetime. Phys Rev X, 2011, 1: 021017

66 Han W, Cao Z. Constructing effective one-body dynamics with numerical energy flux for intermediate-mass-ratio inspirals. Phys Rev D, 2011, 84: 044014

67 Han W. Gravitational waves from extreme-mass-ratio inspirals in equatorially eccentric orbits. Int J Mod Phys D, 2014, 23: 1450064

68 Han W. Fast evolution and waveform generator for extreme-mass-ratio inspirals in equatorial-circular orbits. Class Quant Grav, 2016, 3: 065009

69 Han W. Gravitational radiation from a spinning compact object around a supermassive Kerr black hole in circular orbit. Phys Rev D, 2010, 82: 084013

70 Bunanno A, Damour T. Effective one-body approach to general relativistic two-body dynamics. Phys Rev D, 1999, 59: 084006

71 Bunanno A, Damour T. Transition from inspiral to plunge in binary black hole coalescences. Phys Rev D, 2000, 62: 064015

72 Damour T. The General relativistic two body problem and the effective one body formalism. 2012, arXiv:1212.3169

73 Damour T. Coalescence of two spinning black holes: An effective one-body approach. Phys Rev D, 2001, 64: 124013

74 Bunanno A, Chen Y, Damour T. Transition from inspiral to plunge in precessing binaries of spinning black holes. Phys Rev D, 2006, 74: 104005 


$$
\text { Lett, 2010, 105: } 261101
$$

91 Pan Y, Buonanno A, Buchman L, et al. Effective-one-body waveforms calibrated to numerical relativity simulations: Coalescence of nonprecessing, spinning, equal-mass black holes. Phys Rev D, 2010, 81: 084041

92 Li J, Zhong Y, Pan Y. Gravitational radiation of binaries coalescence into intermediate mass black holes. Commun Theor Phys, 2012, 57: 56-60

93 Buonanno A, Pan Y, Baker J, et al. Approaching faithful templates for nonspinning binary black holes using the effective-one-body approach. Phys Rev D, 2007, 76: 104049

94 Buonanno A, Pan Y, Pfeiffer H, et al. Effective-one-body waveforms calibrated to numerical relativity simulations: Coalescence of nonspinning, equal-mass black holes. Phys Rev D, 2009, 79: 124028

95 Pan Y, Buonanno A, Boyle M, et al. Inspiral-merger-ringdown multipolar waveforms of nonspinning black-hole binaries using the effective-one-body formalism. Phys Rev D, 2011, 84: 124052

96 Taracchini A, Pan Y, Buonanno A, et al. Prototype effective-one-body model for nonprecessing spinning inspiral-merger-ringdown waveforms. Phys Rev D, 2012, 86: 024011

97 Taracchini A, Buonanno A, Pan Y, et al. Effective-one-body model for black-hole binaries with generic mass ratios and spins. Phys Rev D, 2014, 89: 061502

98 Pan Y, Buonanno A, Taracchini A, et al. Stability of nonspinning effective-one-body model in approximating two-body dynamics and gravitational-wave emission. Phys Rev D, 2014, 89: 061501

99 Pan Y, Buonanno A, Fujita R, et al. Post-Newtonian factorized multipolar waveforms for spinning, nonprecessing black-hole binaries. Phys Rev D, 2011, 83: 064003

100 Bernuzzi S, Nagar A, Zenginoglu A. Binary black hole coalescence in the extreme-mass-ratio limit: Testing and improving the effective-one-body multipolar waveform. Phys Rev D, 2011, 83: 064010

101 Barausse S, Buonanno A, Hughes S, et al. Modeling multipolar gravitational-wave emission from small mass-ratio mergers. Phys Rev D, 2012, 85: 024046

102 Taracchini, Buonanno A, Khanna G, et al. Small mass plunging into a Kerr black hole: Anatomy of the inspiral-merger-ringdown waveforms. Phys Rev D, 2014, 90: 084025

103 Buonanno A, Chen Y, Vallisneri M. Detecting gravitational waves from precessing binaries of spinning compact objects: Adiabatic limit. Phys Rev D, 2003, 67: 104025

104 Hannam M, Schmidt P, Bohe A, et al. Simple model of complete precessing black-hole-binary gravitational waveforms. Phys Rev Lett, 2014, 113: 151101 


\title{
The gravitational wave models for binary compact objects
}

\author{
CAI RongGen ${ }^{1}$, CAO ZhouJian ${ }^{2} \&$ HAN WenBiao ${ }^{3}$ \\ ${ }^{1}$ Institute of Theoretical Physics, Chinese Academy of Sciences, Beijing 100190, China; \\ ${ }^{2}$ Academy of Mathematics and Systems Science, Chinese Academy of Sciences, Beijing 100190, China; \\ ${ }^{3}$ Shanghai Astronomical Observatory, Chinese Academy of Sciences, Shanghai 200030, China
}

The gravitational wave detection GW150914 has been realized by LIGO. The theoretical model played an important role in the data analysis. The model not only extracts the signal enveloped in the detector noise, but also recognizes that the source is a binary-black-hole merger. Besides the ground-based detectors like LIGO, pulsar timing arrays and space-based detectors detect gravitational wave in different frequency band. Soon the FAST telescope will partly serve for pulsar timing arrays in the coming year. In the near future, SKA project will strongly enhance the gravitational wave detection with pulsar timing array. Regarding to the space-based detectors, eLISA project is going on in Europe. And the LISA pathfinder works quite well which implies that most instrument techniques for eLISA are ready. Besides eLISA, there are two more plans for space-based detectors in China including Taiji and Tianqin. Among all of these gravitational wave detection projects, theoretical models are very important for signal extraction and parameters inversion. Along the development of the gravitational wave astronomy, the theoretical model research becomes more and more important and urgent. Binary compact objects are among the most important and the most realistic gravitational wave sources for all the above mentioned gravitational wave detection projects. We briefly describe the research status of theoretical models for binary compact objects in this paper. Post Newtonian method, perturbation theory of black hole and numerical relativity are all introduced. Typically these three methods are applied to the inspiral, ringdown and merger stage respectively. And more we also introduced effective one body method which combines the results of all these three methods and constructs a full model for the whole inspiral-merger-ringdown (IMR) process. This model is called effective one body numerical relativity (EOBNR) model which is essential in the data analysis of GW150914.

Currently, post Newtonian method has achieved $4 \mathrm{PN}$ order for the conservative dynamics and 3.5 PN order for gravitational radiation part. Unfortunately the PN order is less for spinning black holes. With higher PN order, ones expect the description is more accurate, and it is valid for nearer separated binary compact objects. Perturbation theory for black holes includes two formalisms. One is metric perturbation which corresponds to the Regge-Wheeler-Zerilli equation. One is curvature perturbation which corresponds to the Teukolsky equation. For Schwarzschild black hole these two formalisms are equivalent. The analytical solution to the Teukolsky equation is not clear yet. In most applications, ones use numerical methods to treat the Teukolsky equation. After the merger of two black holes, the space-time can always be looked as a perturbation of a Kerr black hole. This stage corresponds to the ringdown. So the ringdown stage can always be treated by perturbation theory. In addition, if the masses of the two black hole are extremely different, the effect of the small black hole can be treated as a perturbation to the big black hole. Different to the ringdown description, ones have to care about the motion of the small black hole which is affected by the back reaction of the gravitational wave. In addition, ones need to consider the Teukolsky equation with source. Differently in ringdown case, ones need only care about the initial state of the Teukolsky equation which is determined by the binary merger. Different to both the PN method and the perturbation method, numerical relativity (NR) solves the full Einstein equation without any analytical approximation. In this sense, NR is a robust method to treat any gravitational wave sources even beyond binary compact objects. But ones have to care about two issues when using NR method. One is the massive computational cost. The another is the solution accuracy. Currently spectral method is more efficient and more accurate than finite difference method. But spectral method is less flexible to treat such as precession binary black hole, eccentric binary black hole, large mass ratio binary black hole and other cases. And more, spectral method meets essential difficulties when matter couples to the Einstein equations. So it is desirable to develop a new numerical method which can combine both the advantages of spectral method and finite difference method.

gravitational wave, binary system, numerical relativity, post Newtonian, perturbation theory of black hole, Einstein equations

doi: 10.1360/N972016-00299 